\title{
Constructing imaginative geographies in Genesis
}

\begin{tabular}{|c|c|}
\hline \multicolumn{2}{|c|}{$\begin{array}{l}\text { Author: } \\
\text { José-Alberto Garijo- } \\
\text { Serrano }\end{array}$} \\
\hline \multicolumn{2}{|c|}{$\begin{array}{l}\text { Affiliations: } \\
{ }^{1} \text { Department of Old } \\
\text { Testament Studies, Faculty } \\
\text { of Theology, Pontifical } \\
\text { University of Salamanca, } \\
\text { Salamanca, Spain }\end{array}$} \\
\hline \multicolumn{2}{|c|}{$\begin{array}{l}{ }^{2} \text { Department of New } \\
\text { Testament Studies and } \\
\text { Related Literature, Faculty } \\
\text { of Theology and Religion, } \\
\text { University of Pretoria, } \\
\text { Pretoria, South Africa }\end{array}$} \\
\hline \multicolumn{2}{|c|}{$\begin{array}{l}\text { Description: } \\
\text { The author is participating } \\
\text { as a research fellow in the } \\
\text { project, 'Biblical Theology } \\
\text { and Hermeneutics', directed } \\
\text { by Prof. Dr Andries G. van } \\
\text { Aarde, Senior Research } \\
\text { Fellow in the Dean's Office, } \\
\text { Professor at the Faculty of } \\
\text { Theology and Religion at } \\
\text { the University of Pretoria, } \\
\text { Pretoria, South Africa. }\end{array}$} \\
\hline $\begin{array}{l}\text { Correspondin } \\
\text { José-Alberto } \\
\text { jagarijose@up }\end{array}$ & $\begin{array}{l}\text { author: } \\
\text { arijo-Serrano, } \\
\text { sa.es }\end{array}$ \\
\hline \multicolumn{2}{|c|}{$\begin{array}{l}\text { Dates: } \\
\text { Received: } 07 \text { July } 2021 \\
\text { Accepted: } 26 \text { Aug. } 2021 \\
\text { Published: } 26 \text { Oct. } 2021\end{array}$} \\
\hline \multicolumn{2}{|c|}{$\begin{array}{l}\text { How to cite this article: } \\
\text { Garijo-Serrano, J.A., 2021, } \\
\text { 'Constructing imaginative } \\
\text { geographies in Genesis', HTS } \\
\text { Teologiese Studies/ } \\
\text { Theological Studies 77(2), } \\
\text { a6969. https://doi. } \\
\text { org/10.4102/hts.v77i2.6969 }\end{array}$} \\
\hline \multicolumn{2}{|c|}{$\begin{array}{l}\text { Copyright: } \\
\text { (C) 2021. The Authors. } \\
\text { Licensee: AOSIS. This work } \\
\text { is licensed under the } \\
\text { Creative Commons } \\
\text { Attribution License. }\end{array}$} \\
\hline \multirow[b]{2}{*}{$\begin{array}{l}\text { Read online: } \\
\text { 口保四 }\end{array}$} & \\
\hline & $\begin{array}{l}\text { Scan this QR } \\
\text { code with your } \\
\text { smart phone or } \\
\text { mobile device } \\
\text { to read online. }\end{array}$ \\
\hline
\end{tabular}

This article considers Edward W. Said's proposals on 'imaginative geographies' as suggested in his leading work Orientalism as a tool to analyse the ideological circumstances that shape geographical spaces in the Bible. My purpose is to discuss how these imaginative geographies are present in the patriarchal narratives of Genesis and how they have left their mark on the history of the interpretation of these texts and on the not always easy relations between members of the religious traditions inherited from the Bible (Hebrews, Muslims and Christians). I propose four types of 'imaginative geographies': (1) 'Equalness' is the way to represent what is considered as sharing the own identity. The geography of 'Equalness' defines the spaces of Isaac, Jacob and their families. (2) 'Otherness' is the way to represent the 'Other' as opposite or juxtaposed to one's own identity. A common border is shared, thus kinship relationships can be established. It defines the spaces of Ishmael, Esau/Edom, Lot (Ammon and Moab) and Laban. (3) 'Foreignness' is the way to define what is strange, odd or exotic considered as external to the own identity, in a space set beyond even the space of the 'Other'. Egypt is in Genesis a land of 'Foreignness'. (4) 'Delendness' encompasses whatever claims our same space and therefore threatens our survival and must be destroyed (delendum). As such, processes of annihilation and dominion of Israel on Canaanites and Sichemites are justified.

Contribution: The article applies Said's 'imaginative geographies' as an identity mechanism for the creation of biblical literary spaces. A quadripartite classification ('Equal'/'Other' /' Foreigner' /'Delendum') instead of the usual bipartite one ('Equal' vs. 'Other') is proposed and the consequences for the current coexistence between religious identities inherited from Abraham are shown.

Keywords: orientalism in the Bible; imaginative geographies; otherness in the Bible; Jacob and Esau; Arabs and Ishmaelites; Israelites and Canaanites.

\section{Introduction}

Many current questions and conflicts over cultural identities and borders have their roots in the founding texts of the great religions. The not always easy relationships between Christians, Muslims and Jews in the Mediterranean world and the Middle East are strongly conditioned by how national identities were constructed in the Hebrew Bible. In the last two decades, some studies have addressed the question of how one's own group identity is constructed in the Hebrew Bible in contrast to the 'Others' from a methodological plurality spanning sociology, anthropology, social psychology, postcolonial or ethnicist approaches and literary and historical research (eds. Achenbach, Albertz \& Wöhrle 2011; eds. Albertz \& Wöhrle 2013; eds. Ben Zvi \& Edelman 2014; Brett 2000; ed. Cataldo 2016; Geyser-Fouche \& Fourie 2017; eds. Harlow et al. 2011; eds. Hensel, Nocquet \& Adamczewski 2020; eds. Ro \& Edelman 2021; eds. Sergi, Oeming \& De Hulster 2016a, 2016b). This study will focus on the relationship between group identity and imaginative geography in the patriarchal narratives in the book of Genesis (Gn 11:27-50:26).

Firstly, my point of departure is a literary study of the text that analyses the peculiar relationship between the characters and their own space, following Wellek and Warren's intuition that 'setting is environment and environments, especially domestic interiors, may be viewed as metonymic or metaphoric, expressions of character' (Wellek \& Warren 1949:210) and other literary theorists (Bobes Naves 1985:203; Chatman 1978:138-145; Garrido Domínguez 1996:216-218). Thus, kinship relations, marriages, alliances and ruptures between the heads of family clans are configuring different geographical spaces.

Secondly, I consider that literary studies of narrative space should also analyse the ideological circumstances that give rise to the conformation of geographical spaces. In this sense, Edward W.

Note: Special Collection: Scholarly Voices, sub-edited by Yolanda Dreyer (University of Pretoria). 
Said's proposals on imaginative geographies suggested in his seminal work Orientalism (1978) may be of interest. Said's goal is to unmask the cultural ideas at the basis of literature that justify imperialisms. Orientalism is the cultural creation of 'the East' by 'the West' as an inferior, savage, ungovernable, irrational and fanatical reality. Orientalism creates an idea of what 'they' are as opposed to what 'we' are, an essential 'Otherness' that, in reality, serves to reconstruct one's own identity. According to Said, one of the aspects of Orientalism are 'imaginative geographies', that is, the literary creation of spaces linked to the image of the Orient that distinguish 'our civilised land' from the barbarian 'other lands', those inhabited by 'them' (Said 1978:49-73). A group that inhabits a space will delimit mental rather than physical 'geographical boundaries' that serve to protect its own identity against identities considered barbaric and to separate the known space from the unknown space (Said 1978:54). The imaginative depiction of the Orient privileges certain places representative of its recreated and inferior identity, as the governor's house, the school or the prison (Said 1978:40-41). Based on Said's proposal, Anderson (1983), Bhabha (ed. 1990), Gregory (1994, 1995), Waldenfels (1997), Fludernik (2007) and others have explored the literary construction of national identity through the use of myths and stories and the construction of geographies and spaces. For Mohnike (2007:22-24), the construction of one's own identity involves a tripartite spatial representation: the 'Same' (das Gleich), the 'Other' (das Andere, 'what is not me') and the 'Foreigner' (das Fremde, 'what I do not know and is outside of what I know and can imagine').

Thirdly, every literary text aims to condition the reader's image of the Other, which is displayed in the history of the interpretation of the text according to Gadamer's (1989: 334-341) 'Wirkungsgeschichte' or history of the effects.

I propose a classification of those imaginative geographies in four categories:

1. 'Equalness' is the way of representing what is considered to be encompassed within one's own identity and one's imaginative geography.

2. 'Otherness' is the way of representing the Other as opposed to one's own identity. The 'Other' is located in a space juxtaposed or neighbouring our own. Thus, it is necessary to define the boundaries of Otherness to prevent crossing the limits and bursting into other people's spaces.

3. 'Foreignness' is the way of defining what is foreign, strange, weird or exotic and is considered as something external to one's own identity and 'beyond the Other'. There is no need to establish borders as it is not juxtaposed and there is no danger of overcoming limits.

4. 'Delendness' encompasses everything that claims to occupy the same geographical space as ourselves and therefore threatens our very existence and must be destroyed. Narrative identity justifies the conquest of territory and the destruction of the occupier. I have taken the term delendum from the expression 'Carthago delenda est' attributed to Cato the Elder (ClavadetscherThürlemann 1974).

\section{The imaginative geography of 'Otherness'}

\section{Ishmael}

The imaginative geography of Ishmael is linked to the imaginative geography of the Otherness of the Arab populations considered Ishmael's descendants in biblical literature. Ishmael enjoys a special status as he has received a special blessing from $\mathrm{YHWH}$ in return for the covenant established with Isaac (Gn 16:10-12; 17:18-21; 21:18).

The names of the twelve sons of Ishmael mentioned in his genealogy - 'Nebaioth ... Kedar, Abdeel, Mibsam, Mishma, Dumah, Massa, Hadad, Tema, Jetur, Naphish and Kedemah' (Gn 25:13-15) - are present in texts from the first millennium $\mathrm{BCE}$ referring to populations set down in desert regions between the Levant, the Euphrates river and the Arabian Peninsula. They are called ${ }^{l u}$ Aribi $/{ }^{l u}$ Arbaja in Assyrian sources (Eph'al 1982; Knauf 1989, 1992; Weippert 1974) and Arabs ('ărābîm) in the Bible (Is 13:20; Jr 3:2; Neh 2:19; 4:1; 6:1; 2 Chr $17: 11 ; 21: 16 ; 22: 1 ; 26: 7)$. The mention of Havilah, Assyria and Egypt in Ishmael's genealogy (Gn 25:18) takes us to a vast scenario from Mesopotamia to Africa where Arab nomadic tribes move freely (1 Sm 15:7; Jericke 2013:28-29; Na'aman 1980). It is precisely in the surroundings of that region where YHWH's angel met Hagar in her first escape 'on the way to Shur' (Gn 16:7).

The metaphorical and metonymic relationship of Ishmael's character with his spatial environment is particularly evident in the stories of Hagar's two escapes (Gn 16; 21:9-21). Ishmael will be 'a wild donkey of a man' (Gn 16:12) accustomed to the harsh and lonely life of the wilderness (cf. Jr 2:24; 14:6; Hs 8:9; Ps 104:11; Job 11:12; 24:5), confronted with everything ('his hand against everyone and everyone's hand against him'), out of the land of Canaan but 'in front' ('al penê) of his brothers, keeping a special relationship with them (Hamilton 1995:160; Seebass 1999:261; Westermann 1981:482); initially a place of death threat for Ishmael, the wilderness is the place where 'God was with the boy' and where 'he grew up' (Gn 21:20). Therefore, Ishmael's imaginative geography is characterised by the desert as a place where life is lived in complete freedom but continually threatened, in a struggle for survival and with scarce water sources.

However, the border between the imaginative geographies of Isaac and Ishmael is not so hard. They are constructed with the in-between realms and cross-bordering mechanisms pointed out by Ben Zvi (2014) and they reflect zones of encounter and exchange (Hamilton 1995:169; Römer 1999; Wénin 2016:368; Wöhrle 2011). For instance, after Abraham's death, Isaac settles down precisely at the well of Lachai Roi (Gn 24:62; 25:11), a place linked to Ishmael (Gn 16:13). 
The Ishmaelites' imaginative geography in the Hebrew Bible reflects no negative judgements. Thus, while the book of Jubilees still maintains the positive image of Ishmael (Francis 2012), in Targumic and Rabbinic literature (especially in Targum Pseudo-Jonathan and Pirgei deRabbi Eliezer), Ishmael's depiction is defiled by the controversy between Judaism and Islam in Medieval times (Bakhos 2006; Ohana 1975; Pérez Fernández 2000; Syrén 1994).

\section{Esau and Edom}

The imaginative geography of Esau/Edom is the complete antithesis of the imaginative geography of Jacob/Israel according to the curse his father casts on him - 'away from the fatness of the earth shall your home be and away from the dew of heaven on high' (Gn 27:39) - , and in contrast to Jacob's blessing (Gn 27:27-29). In both formulas, the same terms ('the fatness of the earth' and 'the dew of heaven') are used to describe both the dryness of Esau's land and the fertility of Jacob's land. Furthermore, the preposition min is used in both oracles but with different meanings. In Jacob's blessing, as a partitive: '[of] heaven's dew and [of] earth's richness' (Waltke \& O'Connor 1990:213-214). In Esau's curse, min introduces an argument of origin, which implies resistance/separation ('away from the fatness of the earth... and away from the dew of heaven') marking 'what is missing or unavailable' (Waltke \& O'Connor 1990:214). This element seems to create in Esau an initial false expectation about his blessing that is later tragically refuted, 'a cruel joke, this verse!', as Fokkelman (1991:111) pointed out. However, its authentic meaning remains ambiguous and some authors admit a partitive use of min also in the Esau oracle, such as Jacob (1974:184) and, in rabbinic exegesis, Rashi, who even identifies this rich land as the Italian Greece', following Targum Onkelos and echoing the traditional Jewish identification of Edom with Rome (Hamilton 1995:227).

Esau's imaginative geography is also set 'on high' $\left(m \bar{e}^{\varsigma} \bar{a} l, \mathrm{Gn}\right.$ 27:39), in accordance with the highlands of Mount Seir (cf. Jr 49:16). This may, however, point out to an additional meaning suggested by the paronomasia between elements containing the sound sequence ${ }^{\varsigma}-l: m \bar{e}^{-} \bar{a} l$ ('on high', v. 39) y 'ullô ('his yoke', v. 40). This paronomasia continues in $w^{e \varsigma}$ al harbek $k \bar{a}$ ('by your sword', v. 40) and $m \bar{e} \bar{e}^{\varsigma} a l$ șawwārek $\bar{a}$ ('from your neck', v. $40)$, whereas Jacob's blessing lacks this sound sequence. Genesis Rabbah (BerR 67:7) notices this paronomasia reading $w^{e \uparrow} a l$ harb'k $k$ ('by your sword') as 'ôl harbek $k \bar{a}$ ('the yoke of your sword'). In this way, the imaginative geography of Edom as a highland may include an allusion to his condition as a captive man, subdued to Jacob-Israel as announced in the curse (Gn 27:40).

Esau's genealogy (Gn 36) points out that Esau will dwell in Edom, which is Seir (Gn 36:6-8). Some authors discuss when Esau was linked with Edom/Seir in Genesis narratives (Bartlett 1989:41-44; 175-180; Blum 1984:138; Dicou 1994:137-139; Finkelstein \& Römer 2014:331-332; Nash 2018). In any case, Genesis 36 juxtaposes two lists of population: the 'sons of Esau' (Gn 36:1-19) and the 'sons of Seir' (Gn 36:20-30), which may show up two different and complementary faces of Esau:

Esau in Edom: The story of Esau plays on the paronomasia between the terms Edom ('édôm) and red ('admônî; 'reddish', Gn 25:25; min-hā'ādōm hāa ādōm hazzeh, 'of that red, that red stuff', Gn 25:30), perhaps referring to the colour of the Nubian sandstone of the region (Bartlett 1992:287). Now, Esau's genealogy wearily reminds us that 'Esau is Edom' (v. 1.8.9.19.43) so that the reader may not forget what Esau actually is: He is Edom, that guy who lost his birthrights because of 'that red stuff' (Gn 25:30).

On the other hand, Mount Seir was the territory of the Horrites (Gn 14:6; 29:30; 36:20, 21; Dt 2:12, 22) whom Edom had wiped out. Thus, Seir seems to allude to the warlike and conquering mood of Esau-Seir. The names of some of the chiefs of Esau (Eliphaz, Kenaz, Reuel, Oholibamah, Timna and Amalek) are pointing to a geographical region located in southern Judah and the Negev where there seems to be evidence of Edomite settlement in the 7th-6th centuries BCE (Bartlett 1992:288; Knauf 2001; Tebes 2006). This points out to a more positive imaginative geography than what Esau's curse portrayed: an organised territory with a political structure established even 'before any king reigned over the Israelites' (Gn 36:31; Nm 20:14-21; Dt 2; $1 \mathrm{Sm} \mathrm{8;12)} \mathrm{and} \mathrm{may} \mathrm{reflect} \mathrm{the} \mathrm{frequent} \mathrm{and}$ deep relations between Judea and Idumea from the Persian period until the Hellenistic and Nabatean-Roman periods (Knauf 2001:594).

In biblical literature, Edom is portrayed as the brother of Israel (Gn 32:3; Dt 23:8), but on the other hand, Edom appears as a declared enemy in Numbers 20:14-21; Jeremiah 49:7-22 and in the so-called antiedomite prophetic oracles (Is 34; 63:1-6; Jr 49:7-22; Ezk 25:12-14; Hab; Ps 137:7), probably drawn up in the Persian period as an answer to Edomite intervention in the fall of Jerusalem in 586 BCE (Assis 2006; Bartlett 1982; Dicou 1994; Tebes 2011). Esau/Edom is always present in the Jewish tradition in his ambivalence as both a brother and an enemy. Thus, Edom is identified with Rome in the Talmud and Midrashim and even with the Christians (Hadas-Lebel 1984).

\section{Lot: Ammon and Moab}

Lot's narrative ends with the scene of a tiny group of five people shut down in a narrow cave beyond Zoar (Gn 16:36-38): Lot, his two daughters, and his two sons incestuously born, namely Moab (mồa $b$ ) and Ben-Ammi (ben-'ammî). The character of Lot has a peculiar relationship with his own living space becoming smaller and smaller as the narrative unfolds: from the irrigated wide plain (Gn 13:10-12), the prosperous city of Sodom (Gn 13:12; 19:1), the little town of Zoar (Gn 19:20-23), the far hill (Gn 19:30a) and the narrow cave (Gn 19:30b).

Lot has neither a genealogy nor a list of kings, tribes or cities and not even an assigned territory with defined borders. Actually, the Genesis narrative does not provide an imaginative geography of Moab and the Ammonites. The biblical reader will have to read on to Numbers 21:11-13, 24, Deuteronomy 2:8-11, 18-21, 29, 37 and Judges 11:13-18 to 
know the extent of their territories in Transjordan: the land of Moab confining with the territory of Esau-Seir around the city of Ar (Dt 2, 8-9) and the land of the Ammonites on the hills surrounding the Jabbok river (Dt 2:18-19, 37).

The tiny kingdoms of Moab and of the Ammonites burst into the history of that region during the 9th-6th centuries BCE until they disappeared as independent political entities in the aftermath of the Babylonian invasion in 582-581 BCE (ed. Bienkowski 1992, 2009; De Tarragon 1992; Hübner 1992; Lipiński 2006; Miller 1992). The lack of a detailed imaginative geography of Moab and the Ammonites in Genesis may reflect how Persian-period Judaism envisioned these desolate Transjordanian territories and their inhabitants: only a small memory of their names remained, with no mention of boundaries or special features.

On the other hand, I should point out that whilst the Transjordan kingdoms of Sihon and Og are 'Delenda' and so must be destroyed and their territories occupied (Nm 21:2135; 32:33-38; Dt 3:1-13; Jos 12:1-6), Moab and the Ammonites are considered as 'Others'.

\section{Laban}

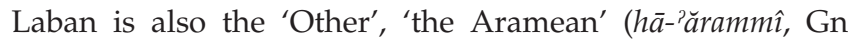
$25: 20 ; 28: 5 ; 31: 20,24)$, with whom the patriarchs have strong kinship ties (eds. Sergi et al. 2016a, 2016b). The account of Jacob's flight (Gn 31:44-32:1) underscores the location of the boundary separating Jacob's and Laban's imaginative geographies: Gilead and Mizpah. Jacob erects a heap $(g \bar{a} l)$ as a witness (' $\bar{e} d$, from which Gilead-gil' $\bar{a} d$ derives) and a mașsēbāh (in paronomasia with mișpāh, Mizpah, 'Watchtower') as landmarks of the non-aggression pact between him and Laban, sealed with a meal. It is possible that 'this separation happens not for ethnic reasons (Rachel and Leah are Arameans) but for religious reasons' (Nocquet 2020:104), Laban's God being 'the God of Abraham and the God of Nahor' (worshipped before Abraham's call as Jos 24:2 remarks), whilst Jacob's God is 'the fear of his father Isaac' (Gn 31:53).

However, Laban has no genealogy, no list of tribes. Laban's sons do not even have a name (Gn 31:1). The imaginative geography of Laban contains just the name of Aram Naharaim (Gn 24:10), the city of Nahor (Gn 24:10), Padan Aram (Gn 25:20; 28:2, 5-7; 31:18; 33:18; 35:9; 35:26; 46:15) and Haran (Gn 27:43; 28:10; 29:4), which are associated with the homeland of the common ancestors (Gn 11:31-32; 12:4-5). Israel defines itself in contrast to this 'Other', Laban and to its imaginative geography, the land of its origins but a definitely left-behind territory.

\section{The imaginative geography of 'Delendness'}

God has given to Abraham and his offspring the land of Canaan (Gn 13:14-17;17:8). The problem is that, astonishingly, the land is already inhabited by another people, the
Canaanites (Gn 12, 6; 13, 7). The land's boundaries of the Canaanites are set in the table of nations:

The territory of the Canaanites extended from Sidon, in the direction of Gerar, as far as Gaza, and in the direction of Sodom, Gomorrah, Admah, and Zeboiim, as far as Lash. (Gn 10:19)

The debate on the ethnic identity of the Canaanites and their relationship with the Israelites has taken up an intense discussion amongst archaeologists and historians (Lemche 1991; Na'aman 1994; Rainey 1996). It seems that the Canaanites as an ethnically different group was a literary creation of postexilic Judaism for the sake of his historiographical project of 'narrating the nation' (Bhabha 1990:1-7): the Canaanites occupy the land of Canaan (Gn $12: 6 ; 13: 7)$, the same geographic space that God has given as an inheritance to Israel (Gn 13:14-17; 17:8), and therefore they must be exterminated, which justifies the practice of herem in the conquest narratives (Nm 21:1-3; Dt 20:10-18; Jos 6:17-21; 8:20-29; 1 Sm 15:1-23). In the Deuteronomic narrative, the Canaanites are a 'Delendum'.

In the Genesis narrative, the geography of 'Delendness' mainly affects the city of Shechem, which seems to represent the whole land of Canaan. Not by chance, Shechem is in the centre of the land of Canaan and was the first place mentioned when Abram and Jacob get into it (Gn 12, 6; 33:18). The story of Dinah (Gn 34) points to the clear and incompatible differentiated identity between the inhabitants of Shechem and the family of Jacob-Israel. Initially, both groups move in their own spaces: Jacob-Israel in the countryside (Gn 33:1819; 34:7) and Hamor-Shechem in the city (Gn 33:18; 34:20, 24, 25, 27-28). However, difficulties arise when Dinah (Gn 34:1) and Hamor (Gn 34:20) get out (yș') of their own space and cross to the opposite space. The people of Shechem propose to break out the border and to become a unique people: 'Make marriages with us; give your daughters to us, and take our daughters for yourselves' (Gn 34:9). Jacob's sons impose circumcision as the only painful condition: (Gn 34:16). This unification proposal includes a clause of the geography of the 'Equalness', in which both groups share the same space (Gn 34:10, 21).

Nevertheless, the rapture of Dinah is taken as an outrage to the national identity of Israel. The reason for defiling ( $\mathrm{tm}^{\text {? }}$ Piel) Dinah (Gn 34:5) and committing infamy (nebālāh) 'in

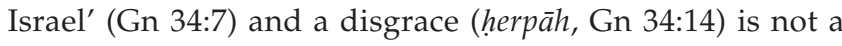
woman's rape (Reuben does so without punishment in Gn $35: 22)$, but giving one of our women to an uncircumcised man, as circumcision is the clear sign of Israel's identity (Gn 17:9-16, 23-27; 21:4). They pretend to be one people when they are not (Bechtel 1994; Garrone 2015). Simeon and Levi intentionally invade the opposite space, burning the city of Shechem to the ground (Gn 34:25-29). The Shichemite will never be an 'Equal' but a 'Delendum'. Jacob suspects the terrible consequences of this action, as then the Canaanites and Jacob's sons will struggle against each other for their survival. 
Dinah's episode shows how a proposal for 'Equalness' can end up with a sentence of 'Delendness'. But it can also happen the other way around. Groups initially categorised as 'Delendum' may in the end be recognised as 'Other' and even as 'Equal', all of which is expressed in a narrative of their own, as in the episodes of the clan of Rahab (Jos 2:1-21; 6:22-25; Nm 31:22) or the Gibeonites (Jos 9). Likewise, there may also be conflictive processes in which a group labelled as 'Equal' becomes a 'Delendum', such as the Benjaminites after the episode of Gibeah's crime (Jdg 20-21). This shows us that the narrative discourse by which groups recognise themselves as 'Equal', 'Other' or 'Delendum' can shift over the course of history.

\section{The imaginative geography of 'Foreignness'}

Egypt appears in the Genesis narratives as an ideal but strange land. The imaginative geography of Egypt depicts it as a fertile, watered country (Gn 13:10), a land of wheat where everyone can go down in times of famine (Gn 12:10; 42:1). However, Israel's sons and the Egyptians maintain a relationship between them different from that of the 'Other' (as Ishmael, Esau/Edom, Laban, Lot), that is, an entity for continuous reference to affirm their own identity. Egypt has got neither a genealogy nor a list of tribes. There is no need to set fixed boundaries with it. In return, Egypt is portrayed as the 'Foreigner', the exotic, the strange, the odd and the different.

Why is Egypt so different? Egypt is the land of the Nile River. In Egypt's imaginative geography, the Nile is the ubiquitous source of its wealth (Gn 41:1-36) and the country's most representative symbol (Jr 46:7-8; Ezk 29:3-5), with its famous floods and ebbs (Am 8:8; 9:5). In Exodus, the Nile is an instrument of oppression, but its waters turned into blood or exhausted are the sign of YHWH's judgement against Egypt (Ex 1:22; 2:1-10; 3:8-9; 7:14-25; Is 19:5-10). Egypt is the land of the Pharaoh, who in biblical literature is almost a metonymy for the country ('... Pharaoh and ... Egypt': Ex 11:1; 18:8, 10; Dt 7:18; 11:3; 1 Sm 6:6; Jr 25:19; Ezk 30; 32). The imaginative geography of Egypt in Genesis conveys the idea of a hierarchised land on whose apex stands the Pharaoh at the first level (Gn 12:10-20; 40:20-23; 41:1-36; 45:16-21; 47:112; 50:4-6). At the second level were Pharaoh's officials: Potiphar (Gn 37:36; 39:1), the prison official (Gn 39:21-23), 'the cupbearer and the baker' (Gn 40:1) and Joseph. At the third level were Pharaoh's officials' servants (Gn 39:11-14; 41:37; 43:19). A great part of Joseph's story is set in buildings referring - in some way or another - to Pharaoh as the supreme authority: Potiphar's house (Gn 39:1-19); the prison where Joseph is closed up (Gn 39:40-40:23); Joseph's house (Gn 42:6-25; 43:17-34; 44:14-45:15) and at last, Pharaoh's house (Gn 41:1-46; 45:2, 16-20; 47:1-10; 50:4-6).

The Egyptian and the Israelite look at each other as 'strangers', as the correlative use of the terms 'Hebrew' ('ibrî) and 'abomination' (to'ēbāh) in Genesis seem to indicate. It is in Egypt where an Israelite may be called a 'Hebrew' ('ibrî,
Loretz 1984), both in Joseph's story (from the mouth of Potiphar's wife; Gn 39:14, 17, the chief cupbearer, Gn 41:12; or the narrator, Gn 43:32) and in Exodus (Ex 2:7-19, 3:18, 5:3, $7: 16 ; 9: 1-3,10: 3)$. The difference between a Hebrew and an Egyptian is so stark that a simple contact between them is considered an 'abomination to Egypt' (tốébat mișraîm) under the form of a food taboo (Gn 43:32) or a refusal to live with shepherds (Gn 46:34) or a refusal of sacrifices to YHWH (Ex 8:22). The term to $\varsigma^{\varsigma} \bar{e} b \bar{a} h$ seems to be an Egyptian loan (bw.t, 'disgusting', Humbert 1960, 1961) and suggests that Israel was aware that other nations and religions also had exclusivist customs and demands (Preuss 2004).

Egypt is the 'Foreigner', the strange country, but it is not unknown or distant. Connections to Egypt are frequent. Egypt is a traditional land of refuge (Galvin 2011). Joseph acknowledges that God brought them there 'to preserve for you a remnant on earth and to keep alive for you many survivors' (Gn 45:7). It is to Egypt where Abram (Gn 12:1020), Hagar (Gn 16:7; cf. Jericke 2013:145-148), Hadad (1 Ki 11:14-22), Jeroboam (1 Ki 11:40; 12:2; 12:24), Jeremiah (Jr 46) and Jesus (Mt 2:13-2) flee, in one way or another.

The 'Egyptian connection' is evident in the story of Ishmael (Gn 16:1, 3; 21:9, 21; 25:12, 18). In the Midrash, Hagar is an Egyptian princess, daughter of Pharaoh (Kadari 2009). Joseph is fully introduced into the Egyptian way of life and customs about clothing, dietary rules and burial practices (Gn 41:14, $42-46 ; 43: 32 ; 50: 2-3,26)$. The experience that Hellenistic Judaism had of being able to develop its own identity in an Egyptian environment, despite the difficulties (Moore 2015), contributed to the widespread reception of the Joseph story, as witnessed, for example, in the Testament of the Twelve Patriarchs and Joseph and Aseneth (Wöhrle 2013).

\section{The imaginative geography of 'Equalness'}

The analysis of the geography of the 'Equalness' should be analysed last because it responds better to the process of identity construction: the identity of the 'Equal' can be defined only after the 'Other', the 'Foreigner' and the 'Delendum' are established. When the Genesis account ends, each group that descended from Abraham has his genealogy, a list of names and an assigned geography in which they have been able to grow and become numerous people. In this way their identity is delimited for everyone... except for Jacob. The sons of Jacob have a list of the 12 people who were born in Padan Aram (Gn 35:22b-26) and of the 70 who went down to Egypt (Gn 46:8-27; cf. Ex 1:1-5), but they do not have a territory. Their geography is still open to the future, perhaps guided by the boundaries that God promises Abraham (Gn 13:14-18; 15:18-21), but it has yet to be realised. The borders of the geography of the 'Equal' have been progressively defined as the borders of the 'Others' have been defined: with Lot in the plain of the Jordan (Gn 13:8-13), with Ishmael in the desert from Havilah to Shur, opposite Egypt in the direction of Assyria (Gn 20:20-21; 25:12-18), 
with the sons of Keturah in the East (Gn 25:1-6), with Laban beyond Mizpah and Gilead (Gn 31:43-55) and with Esau in Seir (Gn 34:16-17). In this way, self-identity is constructed as other identities are created, or rather other identities are created to create one's own identity.

\section{Conclusions}

In this study I have dealt the relationship between the creation of the identity of the 'Other' (understood in a broad sense) and the creation of imaginative spaces and geographies (Said 1978) associated with the 'Other' in the book of Genesis and in the history of its interpretation. I have defined four types of imaginative geographies:

1. The 'Otherness' (properly speaking) reflects the 'Other' as opposed or juxtaposed to the 'Equal' in an imaginative geography in which clear boundaries are defined that cannot be crossed and privileged characteristics and places associated with that geography are observed. The 'Others' are Ishmael (confined to the vast desert region inhabited by the Arabs and updated by Jewish tradition in the followers of Islam), Lot (a refugee in the reduced highlands of Moab and Ammon in Transjordan, to end up disappearing), Esau (who is Edom/Seir, the eternal brother/enemy reincarnated in Idumea, Rome and Christianity) and Laban (in Padan Aram, in Aramaic territory, beyond Mizpah and Gilead, to which there is no return).

2. 'Delendness' defines the group that claims to occupy the same territory as us and which must therefore be destroyed ('delendum') as incompatible with our survival. These are the Canaanites in the Deuteronomic tradition and Shechem in Genesis 31.

3. 'Foreignness' that defines the group whose imaginative geography is not properly opposed or juxtaposed, but exotic, strange and odd or different. In Genesis, Egypt, the land of the Nile and Pharaoh, marks its differences with the Israelites by considering them 'Hebrews' and affected by the 'abomination'.

4. Finally, the 'Equalness' takes up the imagined geography of Abraham's descendants, the land of Canaan, which is defined precisely in contrast to the rest, and in whose territory it is not yet settled when Genesis ends. Equality, moreover, opens up to contacts with 'Otherness' and 'Delendness' that allow for mutual influences and kinship relations.

The main focus of this article is the discussion of imaginative geographies in the book of Genesis. But imaginative geographies can also help to understand other current and past identity processes and conflicts, to which I can only hint because of lack of space. For example, during the Middle Ages, Jews, Muslims and Christians acknowledge themselves as heirs of Abraham to varying degrees, according to the Genesis narrative and recognise mainly each other as an imaginative geography of 'Otherness' with representative spaces (neighbourhoods, worship and gathering places), and defined borders, despite some situations of intolerance (Costa
López 2016; Elukin 2007). However, the recent IsraeliPalestinian conflict has given rise to some hermeneutics of Genesis and the Qur'an that replaces the imaginative geography of 'Otherness' with a geography of 'Delendness', preventing any negotiation and possibility of agreement. This is the case, for example, of Jewish ultra-nationalist sectors in Israel for whom Palestinian Arabs are identified not with Ishmael, but with Amalek and the Philistines (Jacobs 2017; Masahla 2013; Reiter 2010:235-236). Processes of civil wars and genocides - such as those in Bosnia (1992-1995), Rwanda (1994) or in Burma against the Rohinya (2012-2018) - are often associated with national narratives in which group identities (Greenberg 2010; Moshman 2007) and their imaginative geographies are reconstructed in such a way that a group previously considered as 'Equal' or as 'Other' becomes a 'Delendum'. Thus, Edward Said's imaginative geographies may help to understand not only the effects that biblical and non-biblical narratives can have on historical identity processes but also to the identification and dissolution of current conflicts.

\section{Acknowledgements Competing interests}

The author declares that they have no financial or personal relationships that may have inappropriately influenced them in writing this article.

\section{Author's contributions}

J.-A.G.-S. is the sole author of this article.

\section{Ethical considerations}

This article followed all ethical standards for research without direct contact with human or animal subjects.

\section{Funding information}

This research received no specific grant from any funding agency in the public, commercial or not-for-profit sectors.

\section{Data availability}

Data sharing is not applicable to this article as no new data were created or analysed in this study.

\section{Disclaimer}

The views and opinions expressed in this article are those of the author and do not necessarily reflect the official policy or position of any affiliated agency of the author.

\section{References}

Achenbach, R., Albertz, R. \& Wöhrle, J. (eds.), 2011, The foreigner and the Law. Perspectives from the Hebrew Bible and the ancient Near East, Harrassowitz Verlag, Wiesbaden.

Albertz, R. \& Wöhrle, J. (eds.), 2013, Between cooperation and hostility. Multiple identities in ancient Judaism and the interaction with foreign powers, Vandenhoeck \& Ruprecht, Göttingen.

Anderson, B., 1983, Imagined communities, Verso, London. 
Assis, E., 2006, 'Why Edom? On the hostility towards Jacob's brother in prophetic sources', Vetus Testamentum 56(1), 1-20. https://doi.org/10.1163/ prophetic sources', Vetus
156853306775465144

Bakhos, C., 2006, Ishmael on the border. Rabbinic portrayals of the first Arab, State University of New York Press, Albany, NY.

Bartlett, J.R., 1982, 'Edom and the fall of Jerusalem, 587 B.C.', Palestine Exploration Quarterly 114(1), 13-24. https://doi.org/10.1179/peq.1982.114.1.13

Bartlett, J.R., 1989, Edom and the Edomites, JSOT Press, Sheffield.

Bartlett, J.R., 1992, 'Edom', in D.N. Freedman, G.A. Herion, D.F. Graf, J.D. Pleins \& A.B. Beck (eds.), Anchor Bible Dictionary, vol. 2, pp. 287-295, Doubleday, New York, NY.

Bechtel, L.M., 1994, 'What if Dinah is not raped?', Journal for the Study of the Old Testament 19(62), 19-36. https://doi.org/10.1177/030908929401906202

Ben Zvi, E., 2014, 'Othering, selfing, boundarying and cross-boundarying as interwoven with socially shared memories: Some observations', in E. Ben Zvi \& D.V. Edelman (eds.), Imagining the other and constructing Israelite identity in the early Second Temple period, pp. 20-40, Bloomsbury T\&T Clark, London.

Ben Zvi, E. \& Edelman, D.V. (eds.), 2014, Imagining the Other and constructing Israelite identity in the early Second Temple period, Bloomsbury T\&T Clark, London.

Bhabha, H.K. (ed.), 1990, Nation and narration, Routledge, London.

Bienkowski, P. (ed.), 1992, Early Edom and Moab, J.R. Collins, Sheffield.

Bienkowski, P. (ed.), 2009, Studies in Iron Age Moab and neighbouring areas in honour of Michèle Daviau, Peeters, Leuven.

Blum, E., 1984, Die Komposition der Vätergeschichte, Neukirchener Verlag, Neukirchen-Vluyn.

Bobes Naves, M.C., 1985, Teoría general de la novela. Semiología de 'La Regenta', Gredos, Madrid.

Brett, M.G., 2000, Genesis. Procreation and the politics of identity, Routledge, London.

Cataldo, J.W. (ed.), 2016, Imagined worlds and constructed differences in the Hebrew Bible, Bloomsbury T\&T, London.

Chatman, S., 1978, Story and discourse, Cornell University Press, Ithaca, NY.

Clavadetscher-Thürlemann, S., 1974, 'Ceterum censeo Carthaginem esse delendam', Gymnasium 81, 465-474.

Costa López, J., 2016, 'Beyond eurocentrism and orientalism. Revisiting the Othering of Jews and Muslims through medieval Canon Law', Review of International Studies 42(3), 450-470. https://doi.org/10.1017/S0260210515000455

De Tarragon, J.M., 1992, 'Ammon', in D.N. Freedman, G.A. Herion, D.F. Graf, J.D. Pleins \& A.B. Beck (eds.), Anchor Bible Dictionary, vol. 1, pp. 194-196, Doubleday, New York, NY.

Dicou, B., 1994, Edom, Israel's brother and antagonist. The role of Edom in biblical prophecy and story, JSOT Press, Sheffield.

Elukin, J., 2007, Living together, living apart. Rethinking Jewish-Christian relations in the Middle Ages, Princeton University Press, Princeton, NJ.

Eph'al, I., 1982, The ancient Arabs. Nomads on the borders of the Fertile Crescent 9th-5th centuries B.C., Magnes Press, Jerusalem.

Finkelstein, I. \& Römer, T., 2014, 'Comments on the historical background of the Jacob narrative in Genesis', Zeitschrift für die alttestamentliche Wissenschaft 126(3), 317-338. https://doi.org/10.1515/zaw-2014-0020

Fludernik, M., 2007, 'Identity / alterity', in D. Herman (ed.), The Cambridge companion to narrative, pp. 260-273, University Press, Cambridge.

Fokkelman, J.P., 1991, Narrative art in Genesis, 2nd edn., Sheffield Academic Press, Sheffield.

Francis, M., 2012, 'Defining the excluded middle. The case of Ishmael in Jubilees', Journal for the Study of the Pseudepigrapha 21(3), 259-283. https://doi. org/10.1177/0951820712439830

Gadamer, H.G., 1989, Truth and method, 2nd edn., transl. J. Weinsheimer \& D.G. Marshall, Sheen \& Ward, London.

Galvin, G., 2011, Egypt as a place of refuge, Mohr Siebeck, Tübingen.

Garrido Domínguez, A., 1996, El texto narrativo, Síntesis, Madrid.

Garrone, D., 2015, 'Des choses qui ne se font pas en Israël. L’histoire de Dina (Gn 34) et ses enjeux idéologiques', in J.M. Durand, M. Guichard \& T. Römer (eds.), Tabou et transgressions, pp. 145-168, Academic Press Fribourg \& Vandenhoeck \& Ruprecht, Fribourg.

Geyser-Fouche, A. \& Fourie, C., 2017, 'Inclusivity in the Old Testament', HTS Teologiese Studies/Thelogical Studies 73(4), a4761. https://doi.org/10.4102/hts.v73i4.4761

Greenberg, D., 2011, 'Citizenship, national identity, and genocide', in R. Provost \& P. Akhavan (eds.), Confronting genocide, pp. 81-95, Springer, Dordrecht.

Gregory, D., 1994, Geographical imaginations, Blackwell, Cambridge, MA.

Gregory, D., 1995, 'Imaginative geographies', Progress in Human Geography 19(4), 447-485. https://doi.org/10.1177/030913259501900402

Hadas-Lebel, M., 1984, 'Jacob et Esaü ou Israël et Rome dans le Talmud et le Midrash', Revue de l'histoire des Religions 201(4), 369-392. https://doi.org/10.3406/ rhr.1984.4240

Hamilton, V.P., 1995, The book of Genesis. II. Chapters 18-50, Eerdmans, Grand Rapids, MI.
Harlow, D.C., Hogan, K.M., Goff, M. \& Kaminsky, J.S. (eds.), 2011, The 'Other' in Second Temple Judaism, Eerdmans, Grand Rapids, MI.

Hensel, B., Nocquet, D. \& Adamczewski, B. (eds.), 2020, Yahwistic diversity and the Hebrew Bible. Tracing perspectives of group identity from Judah, Samaria, and the diaspora in Biblical traditions, Mohr Siebeck, Tübingen.

Hübner, U., 1992, Die Ammoniter, Otto Harrassowitz, Wiesbaden.

Humbert, P., 1960, 'Le substantif to'eba et le verbe $t b^{\varsigma}$ dans l'Ancien Testament', Zeitschrift für die Alttestamentliche Wissenschaft 70, 217-237. https://doi. org/10.1515/zatw.1960.72.3.217

Humbert, P., 1961, 'L'étymologie du substantif to ${ }^{\Upsilon} e \bar{b} \bar{a}^{\prime}$, in W. Rudolph (ed.), Verbannung und Heimkehr, pp. 157-160, Mohr \& Siebeck, Tübingen.

Jacob, B., 1974, The first book of the Torah, New York, NY.

Jacobs, S.L., 2017, 'Rethinking Amalek in this 21st century', Religions 8(9), 196. https:// doi.org/10.3390/rel8090196

Jericke, D., 2013, Die Ortsangaben im Buch Genesis. Ein historisch-topographischer und literarisch-topografischer Kommentar, Vandenhoeck \& Ruprecht, Göttingen.

Kadari, T., 2009, 'Hagar: Midrash and Aggadah', in M. Shalvi, P.E. Hyman \& D. Ofer (eds.), Jewish women: A comprehensive historical encyclopedia, viewed 22 June 2021, from https://jwa.org/encyclopedia/article/hagar-midrash-and-aggadah.

Knauf, E.A., 1989, Ismael, 2nd edn., O. Harrassowitz, Wiesbaden.

Knauf, E.A., 1992, 'Ishmaelites', in D.N. Freedman, G.A. Herion, D.F. Graf, J.D. Pleins \& A.B. Beck (eds.), Anchor Bible Dictionary, vol. 3, pp. 513-520, Doubleday, New York, NY.

Knauf, E.A., 2001, 'Genesis 36, 1-43', in J.D. Macchi (ed.), Jacob: Commentaire à plusieurs voix de Gen 25-36, pp. 291-300, Labor et Fides, Genève.

Lemche, N.P., 1991, The Canaanites and their land, JSOT Press, Sheffield.

Lipiński, E., 2006, On the skirts of Canaan in the Iron age, Uitgeverij Peeters en Departement Oosterse Studies, Leuven.

Loretz, O., 1984, Habiru - Hebräer. Eine sozio-linguistische Studie über die Herkunft des Gentiliziums 'ibrî vom Appellativum habiru, Walter de Gruyter, Berlin.

Masahla, N., 2013, The Zionist Bible. Biblical precedent, colonialism and the erasure of memory, Routledge, New York, NY.

Miller, J.M., 1992, 'Moab', in D.N. Freedman, G.A. Herion, D.F. Graf, J.D. Pleins \& A.B. Beck (eds.), Anchor Bible Dictionary, vol. 4, pp. 882-893, Doubleday, New York, NY.

Mohnike, T., 2007, Imaginierte Geographien. Der schwedische Reisebericht der 1980er und 1990er Jahre und das Ende des Kalten Krieges, Ergon Verlag, Würzburg.

Moore, S., 2015, Jewish ethnic identity and relations in Hellenistic Egypt. With Walls of Iron?, Brill, Leiden.

Moshman, D., 2007, 'Us and them. Identity and Genocide', Identity. An Internationa Journal of Theory and Research 7(2), 115-135. https://doi. org/10.1080/15283480701326034

Na'aman, N., 1980, 'The Shihor of Egypt and the Shur that is before Egypt', Tel Aviv 7(1-2), 95-109. https://doi.org/10.1179/033443580788441125

Na'aman, N., 1994, 'The Canaanites and their land: A rejoinder', Ugarit-Forschungen 26, 397-418.

Nash, D., 2018, 'Edom, Judah, and converse constructions of Israeliteness in Genesis 36', Vetus Testamentum 68(1), 111-128. https://doi.org/10.1163/1568533012341317

Nocquet, D., 2020, 'The question of Israel's kinship with the Arameans: Rachel and Laban in Gen 31:1-32:1. A Samaritan contribution?', in B. Hensel, D. Nocquet \& B. Adamczewski (eds.), Yahwistic diversity and the Hebrew Bible, pp. 91-107, Moh Siebeck, Tübingen.

Ohana, M., 1975, 'La polémique judéo islamique et l'image d'Ismaël dans Targum Pseudo-Jonathan et dans Pirqê de Rabbi Eliezer', Augustinianum 15(3), 367-381. https://doi.org/10.5840/agstm197515354

Pérez Fernández, M., 2000, 'La tradición targúmica de Agar e Ismael', Miscelánea de Estudios Árabes y Hebraicos. Sección Hebreo 49, 87-103.

Preuss, H.D., 2004, 'tô'ēbāh, t' ' $^{\prime}$ ', in G.J. Botterbeck, H. Ringgren \& H.J. Fabry (eds.), Theological Dictionary of the Old Testament, vol. 15, pp. 591-604, transl. D.E. Green \& D.W. Stott, Eerdmans, Grand Rapids, MI.

Rainey, A.F., 1996, 'Who is a Canaanite? A review of the textual evidence', Bulletin of the American Schools of Oriental Research 304, 1-15. https://doi. org $/ 10.2307 / 1357437$

Reiter, Y., 2010, 'Religion as a barrier to compromise in the Israeli-Palestinian conflict', in Y. Bar-Siman-Tov (ed.), Barriers to peace in the Israeli-Palestinian conflict, pp. 228-263, Konrad Adenauer Stiftung - Jerusalem Institute for Israel Studies, viewed 19 August 2021, from https://jerusaleminstitute.org.il/wp-content/ uploads/2019/06/PUB_barriers_eng.pdf.

Ro, J.U. \& Edelman, D.V. (eds.), 2021, Collective memory and collective identity. Deuteronomy and the Deuteronomistic history in their context, De Gruyter, Berlin.

Römer, T., 1999, 'Isaac et Ismaël, concurrents ou cohéretiers de la promesse? Une lecture de Genèse 16', Études théologiques et religieuses 74(2), 161-172.

Said, E.W., 1978, Orientalism, Penguin, New York, NY.

Seebass, H., 1999, Genesis. II/1. Vätergeschichte I (11,27-22,24), Neukirchener Verlag, Neukirchen

Sergi, O, Oeming, M. \& De Hulster, I.J. (eds.), 2016a, In search for Aram and Israel. Politics, culture, and identity, ORA 20, Mohr Siebeck, Tübingen

Sergi, O., Oeming, M. \& De Hulster, I.J. (eds.), 2016b, The Gilead between Aram and Israel. Political borders, cultural interaction and the question of Jacob and Israelite identity, Mohr Siebeck, Tübingen. 
Syrén, R., 1994, 'Ishmael and Esau in the book of Jubilees and Targum PseudoJonathan', in D.R.G. Beattie \& M.J. McNamara (eds.), The Aramaic Bible, pp. 310315, JSOT Press, Sheffield.

Tebes, J.M., 2006, "'You shall not abhor an Edomite, for he is your brother". The tradition of Esau and the Edomite genealogies from an anthropological perspective', Journal of Hebrew Scriptures 6, 1-30

Tebes, J.M., 2011, 'The Edomite involvement in the destruction of the first Temple', Journal for the Study of the Old Testament 36(2), 219-255. https://doi. org/10.1177/0309089211423731

Waldenfels, B., 1997, Topographie des Fremden. Studien zur Phänomenologie des Fremden 1, Suhrkamp, Frankfurt am Mein.

Waltke, B.K. \& O'Connor, M., 1990, An introduction to biblical Hebrew syntax, Eisenbrauns, Winona Lake.
Weippert, M.H.E., 1974, 'Die Kämpfe des assyrischen Königs Assurpanipal', Die Welt des Orients 7, 39-85.

Wellek, R. \& Warren, A., 1949, Theory of literature, Harcourt, New York, NY.

Wénin, A., 2016, Abraham ou l'apprentissage du dépouillement (Gen 11,27-25,18), Du Cerf, Paris.

Westermann, C., 1981, Genesis. I/2. Genesis 12-36, Neukirchener Verlag, Neukirchen.

Wöhrle, J., 2011, 'Isaak und Ismael. Zum Verhältnis der beiden Abrahamsöhne nach Genesis 17 und Galater 4, 21-32', Evangelische Theologie 71(2), 115-132. https:// doi.org/10.14315/evth-2011-71-2-115

Wöhrle, J., 2013, 'Joseph in Egypt: Living under foreign rule according to the Joseph story and its early intra- and extra-biblical reception', in R. Albertz \& J. Wöhrle (eds.), Between cooperation and hostility, pp. 53-72, Vandenhoeck \& Ruprecht, Göttingen. 